\title{
PENGARUH FASHION INVOLVEMENT TERHADAP IMPULSE BUYING BEHAVIOUR MASYARAKAT SURABAYA DENGAN HEDONIC SHOPPING MOTIVATION DAN POSITIVE EMOTION SEBAGAI VARIABEL INTERVENING PADA MEREK ZARA
}

\author{
Elleinda Yulia Hermanto \\ Pemerhati Fashion Marketing di Surabaya \\ Jl. Siwalankerto 121-131, Surabaya \\ E-mail: ellenyed@gmail.com
}

\begin{abstract}
Abstrak: Perkembangan bisnis ritel di Indonesia, khususnya kota Surabaya menunjukkan pertumbuhan yang signifikan. Selain itu kehidupan masyaraktnya pun juga semakin berkembang dimana semakin konsumtif dan memiliki gaya hidup serta pola belanja masyarakat (konsumen) yang senang mengikuti tren, mode, merek serta kualitas dan terkadang suasana hati juga dapat mempengaruhi seseorang dalam melakukan pembelian. Penelitian ini bertujuan untuk menganalisa pengaruh dari fashion involvement terhadap impulse buying behaviour masyarakat Surabaya dengan hedonic shopping motivation dan positive emotions sebagai variabel intervening pada merek ZARA. Penelitian ini menggunakan kuesioner yang disebar ke 100 responden yang sedang berbelanja di outlet ZARA dan menggunakan teknik analisis Data Partial Least Square (PLS). Hasil Penelitian ini menunjukkan bahwa fashion involvement berpengaruh secara positif dan signifikan terhadap impulse buying, hedonic shopping motivation berpengaruh secara positif dan signifikan terhadap impulse buying dan positive emotions berpengaruh secara positif dan signifikan terhadap impulse buying.
\end{abstract}

Kata kunci: Fashion involvement, Hedonic shopping motivation, Positive emotions, Impulse buying.

\begin{abstract}
The development of retail business in Indonesia, especially Surabaya shows significant growth. More over the life of his society was also growing increasingly consumerist, have a lifestyle and shopping patterns of people (consumers) who like to follow trends, fashion brands as well as better quality and sometimes mood can also affect a person in making a purchase. This study aims to analyze the influence of fashion involvement towards impulse buying behavior Surabaya people with hedonic shopping motivation and positive emotions as an intervening variable in ZARA. This study used a questionnaire which distributed to 100 respondents who were shopping at ZARA and using analytical techniques Data Partial Least Square (PLS). The results of this study indicate that the fashion involvement influence positively and significantly related to impulse buying, hedonic shopping motivation affect positively and significantly related to impulse buying, positive emotions in a positive and significant impact on impulse buying.
\end{abstract}

Keywords: Fashion involvement, Hedonic shopping motivation, Positive emotions, Impulse buying.

\section{PENDAHULUAN}

Dinamika perekonomian bisnis ritel di Indonesia menunjukkan pertumbuhan yang signifikan. Hal itu dikarenakan potensi pasar yang masih cukup besar, seiring dengan berkembangnya trend mode fashion yang mengalami proses modernisasi dalam era globalisasi. Terbukanya peluang pasar domestik menyebabkan banyak pengusaha ritel asing melakukan aktivitasnya di Indonesia yang akhirnya menyebabkan meningkatnya jumlah gerai modern dan banyaknya produk-produk asing yang mewarnai pasar Indonesia. Surabaya termasuk kota yang mengalami perkembangan cukup signifikan dalam hal perdagangan, dimana Surabaya memiliki 33 shopping mall. Hal ini membuat beberapa peritel asing ramairamai membuka gerainya di Surabaya. Hal itu memicu adanya peluang bisnis bagi para pelaku bisnis terutama dibidang fashion untuk membuka gerai fashion modern di dalam mall.
Globalisasi juga menyebabkan adanya perkembangan gaya hidup masyarakat, dimana motivasi hedonis adalah salah satu pemicunya. Bagi masyarakat sekarang berbelanja bukan lagi sebagai hal untuk memenuhi kebutuhan fungsional saja tetapi juga emosional. Berbelanja dijadikan hal untuk refreshing, rekreasi dan hiburan yang dapat memberikan kesenangan. Hal itu didukung oleh pernyataan yang diungkapkan oleh (Semuel, 2005) bahwa hedonic shopping motivation dapat mencerminkan instrumen yang menyajikan secara langsung manfaat dari suatu pengalaman dalam melakukan pembelanjaan seperti kesenangan dan hal-hal baru. Pengalaman positif yang dirasakan konsumen pada saat berbelanja dapat mempengaruhi emosional seseorang dan ketika konsumen tertarik secara emosional seringkali tidak lagi melibatkan rasionalitas dalam proses pengambilan keputusan pembelian.

Fashion merupakan bagian dari gaya hidup masyarakat dan dapat mencerminkan personality 
seseorang. Hal itu didukung oleh pernyataan (Cass'O, 2004) yang mengatakan bahwa keterlibatan pada mode fashion (seperti pakaian) berkaitan sangat erat dengan karakteristik pribadi (yaitu perempuan dan kaum muda) dan pengetahuan fashion, yang nantinya akan mempengaruhi kepercayaan konsumen dalam pengambilan keputusan pembelian. Selain itu bagi masyarakat sekarang berbelanja lebih untuk mengikuti tren, mode, merek serta kualitas sehingga konsumen dengan keterlibatan fashion yang tinggi lebih memungkinkan untuk melakukan pembelian barang secara impulsif.

Impulse buying juga dapat terjadi karena adanya dorongan emosi. Emosi positif seseorang dapat meningkat ketika adanya faktor lingkungan yang mendukung seperti ketertarikan pada item barang ataupun adanya promosi penjualan. Menurut (Rook, D.W. dan Gardner, 1993) konsumen dengan emosi positif menunjukkan adanya pembelian impuls lebih besar karena perasaan menjadi tidak dibatasi, adanya keinginan untuk menghargai diri mereka sendiri, dan tingkat energi yang lebih tinggi.

Impulse buying merupakan suatu pola pembelian atau berbelanja yang sebelumnya belum direncanakan. Menurut (Rook, 1987; Bayley, G. and Nancarrow, 1998; Park, Kim, \& Forney, 2006) Pembelian impulse biasanya terjadi secara tiba-tiba, dimana diawali ketika konsumen memiliki kesenangan yang kompleks dan motivasi yang kuat yang akhirnya berubah menjadi keinginan untuk membeli produk langsung dan biasanya akan menghalangi adanya suatu pertimbangan, pencarian informasi dan alternatif pilihan.

Butik ZARA termasuk dalam kategori perusahaan ritel yang menjual produk fashion dan menyangkut lifestyle. Butik ZARA termasuk gerai yang eksklusif karena ZARA tidak terlalu mementingkan jumlah kuantitas produk, melainkan lebih mengutamakan model pakaian yang beragam dan menyediakan busana-busana yang trendi. Impulse buying yang timbul pada saat melakukan pembelian produk dari merek ZARA adalah karena adanya promo atau diskon, event tertentu seperti musim (autumn, winter, spring, summer), model yang cocok dan bagus dengan diri mereka. Fashion involvement dapat dilihat ketika membeli produk dari merek ZARA dimana lebih mementingkan kualitas, model yang cocok dengan diri mereka serta tren saat ini dibandingkan dengan harga yang tertera.

Berdasarkan latar belakang yang telah dikemukakan, maka permasalahan yang ditimbulkan adalah:

1. Apakah Fashion Involvement berpengaruh terhadap Hedonic Shopping Motivation pada merek ZARA?
2. Apakah Fashion Involvement berpengaruh terhadap Positive Emotions pada merek ZARA?

3. Apakah Hedonic Shopping Motivation berpengaruh terhadap Positive Emotions pada merek ZARA?

4. Apakah Hedonic Shopping Motivation berpengaruh terhadap Impulse buying pada merek ZARA?

5. Apakah Positive Emotions berpengaruh terhadap Impulse buying pada merek ZARA?

6. Apakah Fashion Involvement berpengaruh terhadap Impulse buying pada merek ZARA?

\section{TINJAUAN PUSTAKA}

\section{Fashion Involvement}

Fashion merupakan bagian dari gaya hidup masyarakat dan dapat mencerminkan personality serta status sosial seseorang. Bagi orang yang gemar akan fashion mereka pasti akan sangat memperhatikan penampilannya, sehingga bagi mereka membeli pakaian bukan lagi sebagai memenuhi kebutuhan saja tetapi mereka lebih mengutamakan tren, mode, merek serta kualitas. Hal ini yang menyebabkan masyarakat memiliki keterlibatan terhadap produk fashion. Dalam pemasaran fashion, fashion involvement mengacu pada ketertarikan perhatian dengan kategori produk fashion (seperti pakaian) yang berkaitan sangat erat dengan karakteristik pribadi (yaitu perempuan dan kaum muda) dan pengetahuan fashion, yang nantinya akan mempengaruhi kepercayaan konsumen dalam pengambilan keputusan pembelian. Fashion involvement memiliki hubungan positif dengan pembelian pakaian karena konsumen dengan keterlibatan fashion tinggi lebih mungkin untuk menjadi pembeli pakaian. Oleh karena itu diasumsikan bahwa konsumen dengan keterlibatan fashion yang tinggi lebih mungkin untuk terlibat dalam pembelian impuls berorientasi fashion (Fairhurst, A.E., Good, L.K. \& Gentry, 1989; Seo, J., Hathcote, J.M. and Sweaney, 2001).

\section{Hedonic Shopping Motivation}

Motivasi adalah suatu keadaan yang mendorong seorang individu untuk melakukan suatu tindakan demi pemenuhan suatu kebutuhan dan keinginan. Sedangkan hedonisme adalah pandangan hidup yang menganggap bahwa kesenangan dan kenikmatan materi adalah tujuan utama hidup. Dalam kehidupan berbelanja konsumen didorong oleh motivasi hedonis yang menganggap aktivitas berbelanja sebagai suatu kegiatan pembelian yang didorong dengan perilaku yang berhubungan dengan panca indera, khayalan dan emosi sehingga berbelanja bukan hanya untuk 
membeli produk saja tetapi bagaimana menghabiskan waktu dengan teman-teman, mengikuti tren dan diskon serta kesenangan dan kenikmatan materi sebagai bentuk tujuan utama dalam hidup (Gultekin, B., \& Ozer, 2012; Arnold, M.J., dan Reynolds, 2003).

Arnold, M.J., dan Reynolds, (2003), menggolongkan motivasi hedonis ke dalam enam kategori, yaitu:

\section{1) Adventure shopping:}

Mengarah pada petualangan pembelian.

2) Social shopping:

Motivasi pembelian yang mengarah pada suasana kebersamaan konsumen dengan sahabat atau pengunjung lain.

3) Gratification shopping:

Perasaan tertentu, seperti rasa senang karena berhasil melakukan presentasi, atau tertekan karena sedang mengalami masalah, distro.

4) Idea shopping:

Mengarah pada motivasi seseorang untuk mengetahui tren, fashion dan inovasi terbaru pada saat itu.

5) Role shopping:

Termotivasi melakukan pembelian untuk orang lain.

6) Value shopping:

Mengarah pada motivasi pembelian karena suatu barang sedang dalam progam diskon atau promosi.

\section{Positive Emotions}

Emosi merupakan respon kognitif, gambaran tentang suasana hati seseorang dan perilaku yang muncul akibat stimulus tertentu yang dapat mempengaruhi seseorang dalam mengambil keputusan pembelian. Menurut (Watson, D. and Tellegen, 1985) Emosi dapat diklasifikasikan menjadi 2 bagian orthogonal yaitu emosi positif dan emosi negatif. Emosi positif adalah perasaan positif yang dialami seseorang dimana dapat didatangkan sebelum terjadinya mood seseorang, kecondongan sifat afektif dan reaksi pada lingkungan yang mendukung seperti ketertarikan pada item barang, pelayanan yang diberikan ke konsumen, ataupun adanya promosi penjualan.

Mehrabian, A., and Russell (1974) menyatakan bahwa respon afektif lingkungan atas perilaku pembelian dapat diuraikan oleh 3 variabel yaitu:

\section{Pleasure:}

Mengacu pada tingkat di mana individu merasakan baik, penuh kegembiraan dan bahagia. Pleasure diukur dengan penilaian reaksi lisan ke lingkungan (bahagia sebagai lawan sedih, menye- nangkan sebagai lawan tidak menyenangkan, puas sebagai lawan tidak puas, penuh harapan sebagai lawan berputus asa, dan santai sebagai lawan bosan). Konseptualisasi terhadap pleasure dikenal dengan pengertian lebih suka, kegemaran, perbuatan positif.

2. Arousal:

Mengacu pada gairah atau reaksi yang timbul dalam diri individu akibat adanya rangsangan. Arousal secara lisan dianggap sebagai laporan responden, seperti pada saat dirangsang, ditentang atau diperlonggar.

\section{Dominance:}

Mengacu pada tingkat perasaan yang direspon konsumen saat mengendalikan atau dikendalikan oleh lingkungan. Variabel ini ditandai dengan laporan responden yang merasa dikendalikan sebagai lawan mengendalikan, mempengaruhi sebagai lawan dipengaruhi, terkendali sebagai lawan diawasi, penting sebagai lawan dikagumi, dominan sebagai lawan bersikap tunduk dan otonomi sebagai lawan dipandu.

\section{Impulse Buying}

Impulse buying adalah perilaku pembelian yang tidak direncanakan sebelumnya yang diikuti dengan konflik pikiran dan dorongan emosional. Pembelian impulse biasanya terjadi secara tiba-tiba, dimana diawali ketika konsumen memiliki kesenangan yang kompleks dan motivasi yang kuat karena adanya dorongan dari faktor-faktor eksternal seperti harga promo, distribusi massal, display toko yang menyolok serta kesenangan untuk mengoleksi yang akhirnya berubah menjadi keinginan untuk membeli produk langsung. Konsumen dengan perilaku impulse buying berorientasi fashion lebih memiliki keterlibatan dengan produk (seperti pakaian) karena mereka memiliki pengetahuan akan dunia fashion, kesadaran atau persepsi fashionability yang dikaitkan dengan desain yang inovatif atau gaya seseorang.

Menurut (Stern, 1962) Pembelian yang tidak terencana (impulse buying) dapat diklasifasikan dalam empat tipe:

a. Pure Impulse Buying:

Merupakan pembelian secara impulse yang dilakukan karena adanya luapan emosi dari konsumen sehinga melakukan pembelian terhadap produk di luar kebiasaan pembeliannya.

b. Reminder Impulse Buying:

Merupakan pembelian yang terjadi karena konsumen tiba-tiba teringat untuk melakukan pembelian produk tersebut. Dengan demikian konsumen telah pernah melakukan pembelian sebelumnya 
atau telah pernah melihat produk tersebut dalam iklan.

c. Suggestion Impulse Buying:

Merupakan pembelian yang terjadi pada saat konsumen melihat produk, melihat tata cara pemakaian atau kegunaannya, dan memutuskan untuk melakukan pembelian.

d. Planned Impulse Buying:

Merupakan pembelian yang terjadi ketika konsumen membeli produk berdasarkan harga spesial dan produk-produk tertentu.

\section{Kerangka Konseptual}

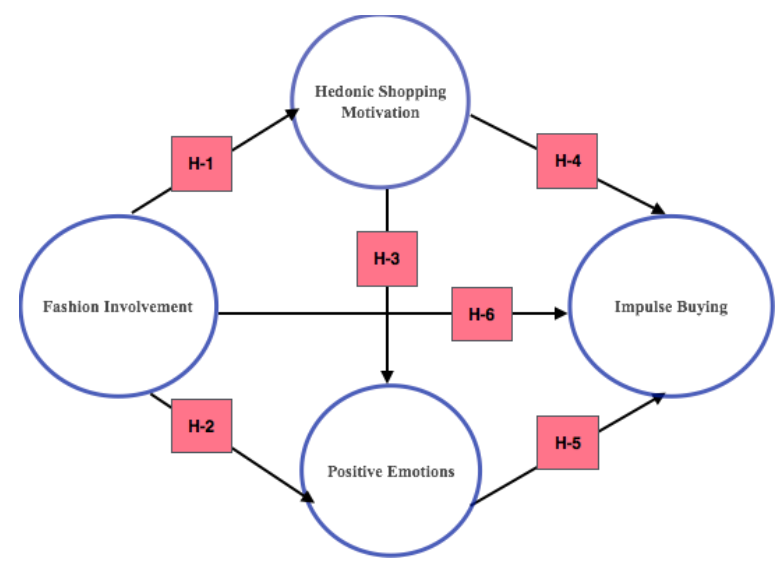

Gambar 1. Kerangka Konseptual

\section{Hipotesis}

Adapun hipotesis yang diajukan pada penelitian ini adalah:

H-1: Fashion Involvement berpengaruh terhadap Hedonic shopping motivation

$\mathrm{H}-2$ : Fashion Involvement berpengaruh terhadap positive emotions

H-3: Hedonic shopping motivation berpengaruh terhadap positive emotion

H-4: Hedonic shopping motivation berpengaruh terhadap impulse buying

H-5: Positive Emotions berpengaruh terhadap Impulse buying

H-6: Fashion involvement berpengaruh terhadap Impulse buying

\section{METODE PENELITIAN}

\section{Populasi dan Sampel}

Populasi adalah kumpulan dari individu dengan kualitas serta ciri-ciri (variabel) yang telah ditetapkan. Populasi yang akan diteliti adalah masyarakat yang berada di Surabaya yang termasuk dalam kategori pecinta fashion, memiliki pengetahuan akan dunia fashion dan mementingkan penampilan.
Teknik pengambilan sampel pada penelitian ini adalah teknik non probability sampling dengan menggunakan teknik convenience sampling yaitu sampel diambil berdasarkan faktor spontanitas. Dengan kata lain sampel diambil/terpilih karena ada ditempat dan waktu yang tepat. Kriteria dari penelitian ini adalah responden sedang berbelanja merek ZARA.

Penelitian ini menggunakan sampel sebanyak 100 responden berdasarkan pada pertimbangan tingkat keyakinan 0,95 dengan $\alpha 0,05$ dan kesalahan yang mungkin terjadi tidak lebih dari $10 \%$

\section{Definisi Operasional Variabel}

Definisi operasional variabel yang akan digunakan dalam penelitian ini terdiri dari 4 variabel, yaitu:

- Variabel eksogen/independen, yaitu Fashion involvement (X1): adalah tingkat keterlibatan konsumen terhadap produk fashion seperti pakaian karena memiliki pengetahuan terhadap dunia fashion (tren, mode, merek serta kualitas) dan berkaitan dengan karateristik pribadinya yang akhirnya mempengaruhi dalam pengambilan keputusan pembelian

- Variabel intervening yaitu, Hedonic shopping motivation (Y1): adalah keadaan yang menyenangkan ketika seseorang sedang berada di pusat perbelanjaan dan mendapatkan pengalaman berbelanja yang menghibur dan emosional, sehingga timbul motivasi berbelanja yang digunakan untuk rekreasi, hiburan, bersosialisasi dengan teman atau browsing tanpa melakukan pembelian produk

- Positive Emotions (Y2): adalah emosi yang mampu menghadirkan perasaan positif terhadap seseorang yang mengalaminya. Emosi positif dapat terjadi ketika seseorang memiliki ketertarikan yang menyenangkan pada item barang tertentu, pelayanan yang diberikan ke konsumen, ataupun adanya promosi penjualan.

- Variabel dependen yaitu, Impulse buying (Z1): adalah perilaku pembelian yang tidak direncanakan sebelumnya yang diikuti dengan dorongan emosional dan faktor-faktor eksternal seperti harga promo, distribusi massal, display toko yang menyolok serta kesenangan untuk mengoleksi yang akhirnya berubah menjadi keinginan untuk membeli produk langsung dan biasanya menghindari adanya pertimbangan sebagai sebuah pola belanja.

\section{Teknik Analisis Data}

Pengujian hipotesis pada penelitian ini dilakukan dengan menggunakan teknik path analysis. Pengujian 
statistik pada model path analysis dalam penelitian ini dilakukan dengan menggunakan metode partial least square regression. Pengolahan data menggunakan program smartPLS.

\section{HASIL PENELITIAN DAN PEMBAHASAN}

Evaluasi Path Coefficient dan Coefficient of Determination (R 2).

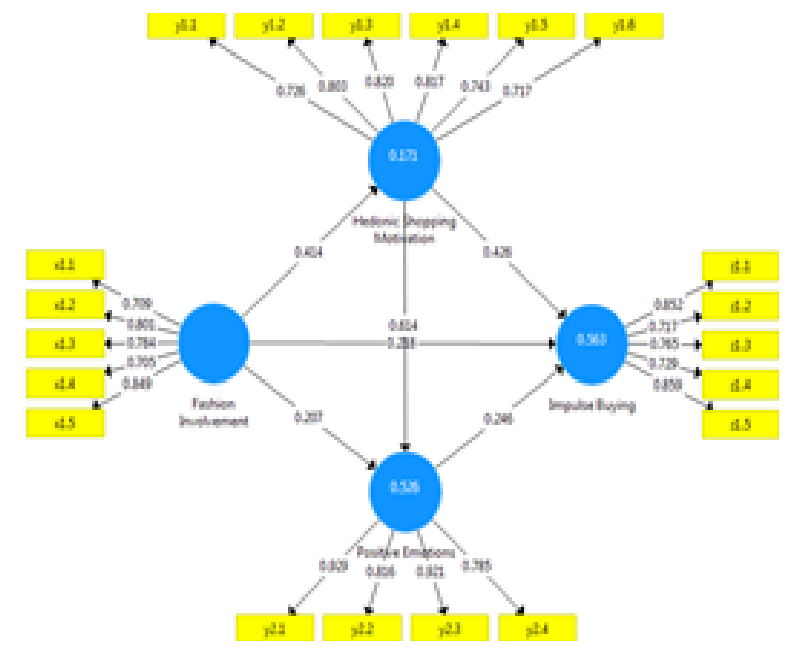

Gambar 2. Path Coefficient dan Coefficient of Determination

Pada analisa path coefficient ini dapat diketahui bahwa variabel hedonic shopping motivation dan positive emotions tidak dapat menjadi variabel intervening. Hal ini dapat terjadi karena hedonic shopping motivation pada merek ZARA hampir tidak ada karena jika melihat secara segmentasi ZARA merupakan merek yang memiliki tingkat paling rendah dalam piramida segmentasi yaitu mass market. Tingkat mass market memiliki karakteristik yaitu produk yang dimiliki cenderung homogen, memiliki harga yang dianggap paling murah bagi konsumen, memiliki biaya yang paling rendah bagi perusahaan dimana efisiensi dianggap menjadi kunci sukses sebuah perusahaan dan hal ini memang diterapkan oleh merek ZARA. Dari segi harga yang dianggap paling murah bagi konsumen dapat dijelaskan bahwa bagi orang luar negeri ZARA merupakan merek dengan harga yang murah dan dianggap seperti pakaian biasa sedangkan jika di Indonesia ZARA dianggap merek yang mahal dan eksklusif, hal ini dapat terjadi karena adanya perbedaan pendapatan per kapita dan nilai mata uang antara Indonesia dengan luar negeri. Selain itu ZARA di Indonesia memilih membuka outletnya di mall karena orang kalangan menengah ke atas cenderung untuk berbelanja di mall namun di luar negeri seperti di USA, Zara memposisikan tempatnya di jalan-jalan besar. Positive emotions juga tidak dapat terbentuk dengan baik ketika hedonic shopping motivation seseorang hampir tidak ada. Emosi positif seseorang dapat terbentuk ketika mereka memiliki pengalaman belanja yang positif dimana berbelanja tidak hanya sebagai memenuhi kebutuhan fungsional saja tetapi juga emosional yang dapat memberikan kesenangan dan kegembiraan.

Sementara itu, nilai coefficient of determination $\left(\mathrm{R}^{2}\right)$ yang pada gambar ditunjukan pada angka di dalam lingkaran dimana variabel hedonic shopping motivation dipengaruhi oleh variabel fashion involvement dengan nilai varian sebesar 0,17 , variabel positive emotions dipengaruhi oleh fashion involvement dan hedonic shopping motivation dengan nilai varian sebesar 0,526 dan variabel impulse buying dipengaruhi oleh variabel fashion involvement, hedonic shopping motivation dan positive emotions dengan nilai varian 0,563 .

\section{T-statistics}

Tabel 1. T-statistics

\begin{tabular}{|c|c|c|c|c|}
\hline & $\begin{array}{l}\text { Original } \\
\text { Sample } \\
(\mathrm{O})\end{array}$ & $\begin{array}{c}\text { Sample } \\
\text { Mean } \\
(\mathrm{M})\end{array}$ & $\begin{array}{c}\text { Standard } \\
\text { Deviasi } \\
(\mathrm{STDEV})\end{array}$ & $\begin{array}{c}\text { T Statistics } \\
(|\mathrm{O} / \mathrm{STDEV}|)\end{array}$ \\
\hline $\begin{array}{l}\text { Fashion } \\
\text { involvement } \\
\rightarrow \text { Hedonic } \\
\text { shopping } \\
\text { motivation }\end{array}$ & 0,414 & 0,429 & 0,088 & 4,713 \\
\hline $\begin{array}{l}\text { Fashion } \\
\text { involvement } \\
\rightarrow \text { Positive } \\
\text { emotions }\end{array}$ & 0,207 & 0,214 & 0,082 & 2,527 \\
\hline $\begin{array}{l}\text { Hedonic } \\
\text { shopping } \\
\text { motivation } \rightarrow \\
\text { Positive } \\
\text { emotions }\end{array}$ & 0,614 & 0,612 & 0,072 & 8,514 \\
\hline $\begin{array}{l}\text { Hedonic } \\
\text { shopping } \\
\text { motivation } \rightarrow \\
\text { Impulse } \\
\text { buying }\end{array}$ & 0,426 & 0,432 & 0,093 & 4,579 \\
\hline $\begin{array}{l}\text { Positive } \\
\text { emotions } \rightarrow \\
\text { Impulse } \\
\text { buying }\end{array}$ & 0,246 & 0,247 & 0,105 & 2,342 \\
\hline $\begin{array}{l}\text { Fashion } \\
\text { involvement } \\
\rightarrow \text { Impulse } \\
\text { buying }\end{array}$ & 0,218 & 0,213 & 0,097 & 2,244 \\
\hline
\end{tabular}

$T$-statistics pada pengaruh fashion involvement terhadap hedonic shopping motivation menunjukkan angka 4,713, artinya fashion involvement berpengaruh 
signifikan terhadap hedonic shopping motivation. Tstatistics pada pengaruh fashion involvement terhadap positive emotions menunjukkan angka 2,527 , artinya fashion involvement berpengaruh signifikan terhadap positive emotions. T-statistics pada pengaruh hedonic shopping motivation terhadap positive emotions menunjukkan angka 8,514, artinya hedonic shopping motivation berpengaruh signifikan terhadap positive emotions. T-statistics pada pengaruh hedonic shopping motivation terhadap impulse buying menunjukkan angka 4,579, artinya hedonic shopping motivation berpengaruh signifikan terhadap impulse buying. $T$ statistics pada pengaruh positive emotions terhadap impulse buying menunjukkan angka 2,342, artinya positive emotions berpengaruh signifikan terhadap impulse buying. T-statistics pada pengaruh fashion involvement terhadap impulse buying menunjukkan angka 2,244, artinya fashion involvement berpengaruh signifikan terhadap impulse buying.

\section{Uji Hipotesis}

Tabel 2. Kesimpulan Hipotesis

\begin{tabular}{|c|c|c|}
\hline Hipote: & sKeterangan & T-statistics \\
\hline $\mathrm{H}_{1}$ & Terdapat pengaruh signifikan dari & 4,713 \\
\hline & Fashion involvement terhadap & \\
\hline & Hedonic shopping motivation & \\
\hline $\mathrm{H}_{2}$ & Terdapat pengaruh signifikan dari & 2,527 \\
\hline & Fashion involvement terhadap & \\
\hline & Positive emotions & \\
\hline H3 & Terdapat pengaruh signifikan dari & 8,514 \\
\hline & $\begin{array}{l}\text { Hedonic shopping motivation } \\
\text { terhadap Positive emotions }\end{array}$ & \\
\hline $\mathrm{H} 4$ & Terdapat pengaruh signifikan dari & 4,579 \\
\hline & $\begin{array}{l}\text { Hedonic shopping motivation } \\
\text { terhadap Impulse buying }\end{array}$ & \\
\hline H5 & Terdapat pengaruh signifikan dari & 2,342 \\
\hline & $\begin{array}{l}\text { Positive emotions terhadap Impulse } \\
\text { buying }\end{array}$ & \\
\hline H6 & Terdapat pengaruh signifikan dari & 2,244 \\
\hline & Fashion involvement terhadap & \\
\hline & Impulse buying & \\
\hline
\end{tabular}

Pengaruh antar variabel dikatakan bersifat signifikan apabila nilai $T$-statistics lebih besar dari angka 1,96. Sehingga diketahui bahwa berdasarkan Tabel 2, terdapat pengaruh signifikan antara variabel fashion involvement terhadap hedonic shopping motivation, terdapat pengaruh signifikan antara variabel fashion involvement terhadap positive emotions, terdapat pengaruh signifikan antara hedonic shopping motivation terhadap positive emotions, terdapat pengaruh signifikan antara hedonic shopping motivation terhadap impulse buying, terdapat pengaruh signifikan antara positive emotions terhadap impulse buying dan terdapat pengaruh yang signifikan antara fashion involvement terhadap impulse buying.

\section{PEMBAHASAN}

\section{Fashion involvement terhadap Hedonic shopping motivation}

Pada hasil penelitian ini dapat diketahui bahwa fashion involvement mempunyai pengaruh yang signifikan terhadap hedonic shopping motivation dengan nilai uji $T$-statistics $>1,96$ yaitu sebesar 4,713. Hal ini dikarenakan konsumen yang peduli dan cinta terhadap dunia fashion biasanya memiliki keterlibatan tinggi dengan fashion terbaru karena mereka akan berusaha untuk mengikuti tren dan mode, mereka juga akan berusaha untuk memenuhi kebutuhan fashion mereka dengan cara berbelanja produk fashion atau berpakaian dengan cara yang unik dan menarik untuk dipamerkan dan biasanya mengacu adanya kecenderungan motivasi berbelanja secara hedonis, selain itu konsumen yang peduli dan cinta dengan dunia fashion lebih cenderung memiliki pengetahuan yang baik dengan produk-produk fashion. ZARA merupakan merek yang memiliki perputaran produk yang cepat dan mengikuti tren dimana ZARA sangat cepat dalam mengganti model pakaiannya sehingga model pakaian yang di display di outlet ZARA selalu baru dan mengikuti tren, hal ini membuat konsumen berusaha mencari informasi tentang produk fashion dari merek ZARA yang up to date dengan model pakaian yang bagus dan unik, selain itu ZARA sangat menjaga kualitas produk mereka sehingga bahan yang dipakai bagus dan dijahit secara rapi sehingga hal itu membuat konsumen merasa nyaman dan senang dengan produk ZARA. Hasil ini mendukung temuan sebelumnya yaitu (Chang, E.B., Leslie, D.,\& Franchis, 2004; Park, Kim, \& Forney, 2006) konsumen yang memiliki keterlibatan khusus dalam produk-produk fashion biasanya memicu adanya motivasi belanja secara hedonis karena semakin tinggi tingkat keterlibatan konsumen dengan produk-produk fashion, semakin mereka akan meningkatkan pembelian produk fashion.

\section{Fashion involvement terhadap positive emotions}

Pada hasil penelitian ini dapat diketahui bahwa fashion involvement mempunyai pengaruh yang signifikan terhadap positive emotions dengan nilai uji T-statistics > 1,96 yaitu sebesar 2,527. Hal ini dikarenakan konsumen dengan emosi yang positif lebih dapat mencerminkan sejauh mana seseorang 
dalam kondisi energi tinggi, konsentrasi penuh, dan keterlibatan yang menyenangkan dengan item produk tertentu serta konsumen sangat antusias dengan model fashion yang bervariasi dan puas dengan kualitas produk fashion yang dijual. Hal ini dapat terjadi ketika konsumen merasa nyaman dan senang ketika menggunakan produk-produk dari merek ZARA karena bahan pakaian yang digunakan bagus atau ketika konsumen dapat menemukan dengan mudah model produk dari ZARA yang sesuai dengan postur tubuhnya. Hasil ini mendukung penelitian sebelumnya yaitu (Park et al., 2006) yang menyatakan bahwa keterlibatan fashion berpengaruh terhadap emosi positif karena keterlibatan fashion dapat meningkatkan pengalaman emosional konsumen ketika berbelanja dan emosi postif dapat meningkat ketika konsumen merasa sangat bergairah dan puas selama berbelanja dan ketika mereka mampu mengekspresikan keingintahuannya terhadap produk fashion.

\section{Hedonic shopping motivation terhadap positive emotions}

Pada hasil penelitian ini dapat diketahui bahwa hedonic shopping motivation mempunyai pengaruh yang signifikan terhadap positive emotions dengan nilai uji $T$-statistics $>1,96$ yaitu sebesar 8,514. Hal ini dikarenakan hedonic shopping motivation merupakan motivasi belanja yang mengacu pada tingkat persepsi di mana berbelanja tidak hanya untuk memenuhi kebutuhan fungsional saja tetapi juga emosional yang akhirnya memberikan bermacam perasaan positif dan kesenangan. Hal ini dapat terjadi karena konsumen merasa senang ketika dilayani dengan baik oleh SPG ZARA pada saat berbelanja, konsumen dapat dengan mudah menemukan produk yang mereka inginkan, dengan berbelanja mereka bisa menghilangkan kepenatan dan dengan berbelanja mereka lebih dapat mengeksplor pengalamannya di dunia fashion. Hasil ini mendukung temuan sebelumnya yaitu (Semuel, 2005) bahwa Hedonic Shopping Motivation dapat mencerminkan instrumen yang menyajikan secara langsung manfaat dari suatu pengalaman dalam melakukan pembelanjaan seperti kesenangan dan halhal baru. Oleh karena itu pengalaman positif yang dirasakan konsumen pada saat berbelanja dapat mempengaruhi emosional seseorang.

\section{Hedonic shopping motivation terhadap impulse buying}

Pada hasil penelitian ini dapat diketahui bahwa hedonic shopping motivation mempunyai pengaruh yang signifikan terhadap impulse buying dengan nilai uji T-statistics > 1,96 yaitu sebesar 4,579. Hal ini dikarenakan konsumen lebih cenderung terlibat dalam perilaku impulse buying ketika termotivasi atau digairahkan oleh keinginan hedonis atau dengan alasan non-ekonomi, antara lain; kesenangan, fantasi dan kepuasan emosional sehingga seringkali seseorang tidak lagi melibatkan rasionalitas dalam proses pengambilan keputusan pembelian. Konsumen yang senang mengikuti tren dan mengeksplor pengalamannya di dunia fashion cenderung melakukan pembelian secara tidak direncanakan ketika melihat ada keluaran produk-produk terbaru yang sedang tren dari ZARA atau jika sedang melihat ada harga khusus pada produk tertentu. Hasil ini mendukung temuan sebelumnya yaitu (Hirschman, E. C., \& Holbrook, 1982) bahwa konsumsi hedonik seseorang termasuk aspek perilaku yang berkaitan dengan multi-sensorik, fantasi, dan konsumsi emosional yang didorong oleh beberapa manfaat seperti perasaan menyenangkan ketika menggunakan suatu produk dan daya tarik estetis.

\section{Positive emotions terhadap impulse buying}

Pada hasil penelitian ini dapat diketahui bahwa positive emotions mempunyai pengaruh yang signifikan terhadap impulse buying dengan nilai uji $T$ statistics $>1,96$ yaitu sebesar 2,342. Hal ini dikarenakan konsumen dengan emosi positif menunjukkan adanya pembelian impuls lebih besar karena adanya perasaan yang tidak dibatasi, bersemangat, senang dan puas. Hal ini dapat terjadi ketika konsumen merasa bersemangat untuk membeli ketika melihat produk new arrival yang di display di manekin, merasa bersemangat ketika SPG ZARA menawarkan berbagai produk new arrival dengan model yang bagus dan cocok dengan dirinya. Hasil ini mendukung penelitian sebelumnya yaitu (Weinberg, P., \& Gottwald, 1982) mengemukakan bahwa pembelian impuls terjadi karena adanya perasaan yang lebih besar, kesenangan, antusiasme, dan sukacita.

\section{Fashion involvement terhadap impulse buying}

Pada hasil penelitian ini dapat diketahui bahwa fashion involvement mempunyai pengaruh yang signifikan terhadap impulse buying dengan nilai uji $T$ statistics $>1,96$ yaitu sebesar 2,244. Hal ini dikarenakan konsumen dengan perilaku impulse buying berorientasi fashion lebih memiliki keterlibatan dengan produk (seperti pakaian) karena mereka memiliki pengetahuan akan dunia fashion, kesadaran atau persepsi fashionability yang dikaitkan dengan desain yang inovatif atau gaya seseorang, sehingga seringkali 
konsumen dengan tingkat keterlibatan yang tinggi memiliki kebiasaan untuk berpakaian modis dan mengikuti tren atau model pakaian terbaru. Zara merupakan merek yang up to date sekaligus mengikuti tren dimana model pakaian yang di display di outlet ZARA cepat berubah, selain itu Zara juga merupakan merek yang fashionable karena produkproduknya memiliki desain yang bagus dan di desain dengan mengikuti gaya luar negeri yang disesuaikan dengan postur tubuh masyarakat setiap negara. ZARA juga memiliki tingkat turnover yang tinggi terhadap produknya, sehingga produk-produk yang di display selalu terlihat baru dan mengikuti tren, oleh karena itu tidak mengherankan konsumen ZARA kemudian menjadi pembeli yang impulsif (impulsive buyer). Hasil ini mendukung penelitian sebelumnya yaitu (Jay, 2011) yang mengatakan bahwa konsumen dengan keterlibatan fashion yang tinggi akan lebih mudah terlibat pembelian impulsif produk fashion dengan model-model terbaru. Sedangkan berdasarkan penelitian (Cass'O, 2004) fashion involvement mengacu pada ketertarikan perhatian dengan kategori produk fashion (seperti pakaian) yang berkaitan sangat erat dengan karakteristik pribadi (yaitu perempuan dan kaum muda) dan pengetahuan fashion, yang mempengaruhi kepercayaan konsumen dalam pengambilan keputusan pembelian.

\section{KESIMPULAN DAN SARAN}

\section{Kesimpulan}

Berdasarkan hasil penelitian mengenai analisa pengaruh fashion involvement terhadap impulse buying masyarakat Surabaya dengan hedonic shopping motivation dan positive emotions sebagai variabel intervening pada merek ZARA dapat ditarik kesimpulan bahwa fashion involvement merupakan variabel yang berpengaruh dalam menciptakan hedonic shopping motivation, positive emotion dan impulse buying pada merek ZARA. Hal ini dikarenakan keterlibatan khusus dengan produk fashion dapat meningkatkan pengalaman emosional konsumen ketika berbelanja yang akhirnya mempengaruhi kepercayaan konsumen dalam hal pengambilan keputusan pembelian.

\section{Saran}

Untuk dapat meningkatkan impulse buying konsumennya ZARA dapat menggunakan fashion thematic di outletnya, misalnya ketika sedang natal outlet ZARA di desain dengan tema natal dan pakaian yang di display misalnya adalah pakaian keluaran terbaru yang memiliki warna cerah seperti warna merah yang kemudian dipadu padankan dengan warna yang sesuai agar tetap terlihat menarik dan tetap terlihat classic.

Untuk Peneliti Selanjutnya dapat menambahkan variabel bebas (X) diluar variabel bebas yang digunakan dalam penelitian ini seperti store atmosphere. Hal ini dikarena melihat ZARA memiliki outlet yang bagus dan terlihat eksklusif yang dapat memungkinkan orang merasa nyaman dan senang ketika berbelanja di outlet ZARA.

\section{DAFTAR PUSTAKA}

Arnold, M.J., dan Reynolds, K. E. (2003). Hedonic Shopping Motivation. Journal of Retailing, 79, pp. 77-95.

Bayley, G. and Nancarrow, C. (1998). Impulse purchasing: a qualitative exploration of the phenomenon. Qualitative Market Research: An International Journal, 1(No. 2), pp. 99-114.

Cass'O, A. (2004). Fashion clothing consumption: antecedents and consequences of fashion clothing involvement. European Journal of Marketing, 38(7), pp. 869-82.

Chang, E.B., Leslie, D.,\& Franchis, S. K. (2004). Gender Differences in the Dimensional Structure of Apparel Shopping Satisfaction Among Korean Consumers: The Role of Hedonic Shopping Value. Clothing and Textiles Research Journal, 22, 185.

Fairhurst, A.E., Good, L.K. \& Gentry, J. W. (1989). Fashion Involvement: an instrument validation procedure. Clothing and Textiles Research Journal, 7(3), pp. 10-14.

Gultekin, B., \& Ozer, L. (2012). The Influence of Hedonic Motives and Browsing on Impulse Buying. Journal of Economics and Behavioral Studies, 4(No. 3), pp. 180-189.

Hirschman, E. C., \& Holbrook, M. B. (1982). Hedonic Consumption: Emerging Concepts, Method and Propositions. Journal of Marketing, 46(No. 3), pp. 92-101.

Jay, S. R. (2011). Consumers attitude and Shopping Intentions toward Pop-up Fashion Stores. Journal of Global Fashion Marketing, 139-147.

Mehrabian, A., and Russell, J. A. (1974). An Approach to Environmental Psychology. in Fisher, Feffrey D., Paul A. Bell, and Andrew Baum (1984). In Environmental Psycholog (2nd ed.). New York: Holt, Rinehart and Winston.

Park, E. J., Kim, E. Y., \& Forney, J. C. (2006). A structural model of fashion-oriented impulse buying behavior. Journal of Fashion Marketing 
and Management, 10(4), 433-446. http://doi. org/10.1108/13612020610701965.

Rook, D.W. dan Gardner, M. P. (1993). In the mood: impulse buying's affective antecedents. Research in Consumer Behavior, 6, pp. 1-26.

Rook, D. W. (1987). The impulse buying. Journal of Consumer Research, 9(14), pp. 189-199.

Semuel, H. (2005). Response Lingkungan Berbelanja Sebagai Stimulus Pembelian. Jurnal Manajemen Kewirausahaan, 7(2).

Seo, J., Hathcote, J.M. and Sweaney, A. L. (2001). Casualwear shopping behavior of college men in
Georgia, USA. Journal of Fashion Marketing and Management, 5(No. 3), pp. 208-22.

Stern, H. (1962). The significance of impulse buying today. Journal of Marketing, 26(4), pp. 59-62.

Watson, D. and Tellegen, A. (1985). Toward a consensus structure of mood. Psychological Bulletin, 98(No. 2), pp. 219-35.

Weinberg, P., \& Gottwald, W. (1982). Impulsive consumer buying as a result of emotions. Journal of Business Research, 10(1), 43-57. Retrieved from http://dx.doi.org/10.1016/0148-2963(82) 90016-9. 